\title{
Rettstolking og rettssikkerhet i et norsk perspektiv ${ }^{1}$
}

\author{
Asse Johnsen \\ Universitetet i Bergen \\ Institutt for fremmedsprak \\ Ase.johnsen@if.uib.no
}

\section{Keywords: \\ court interpreting \\ legal protection \\ Norway}

Register of Interpreters

professionalism 


\section{Abstract}

\section{Court interpreting and legal protection in Norway}

This article comprises a critical report on the status of court interpreting in Norway. The findings are based on an analysis of examples from the Bergen City Court and a survey of court interpreters in Norway. The first part of the article examines the activity of interpreting as a profession, and to what extent the interpreter is a visible professional in a Norwegian court. Thereafter I argue that the Norwegian National Register of Interpreters, with its five-tier classification system, legitimizes the use in Norwegian courts of 'interpreters' who have completed no interpreter training and/or possess no interpreting accreditation. While the article demonstrates that improvements have been made in the field of court interpreting in Norway since the start of this millennium, the continuing lack of professional interpreters poses a threat to the legal rights of defendants, as well as hampering the ability of professionals in the court properly to conduct their duties. 


\section{Innledning}

$\varnothing k t$ innvandring og et åpent Europa uten samme grensekontroll som før, har gjort at tolking innenfor rettssystemet er blitt en dagligdags foreteelse. Dette har ført til at tolking er blitt satt oftere på dagsorden enn før, og vi ser stadig oppslag i media om tolking i retten. Til tross for at det finnes mange dyktige tolker som gjør en meget god jobb, ofte under vanskelige arbeidsforhold, gir mediaoppslagene som oftest eksempler på dårlig tolking, og det er denne sistnevnte, sammen med tolkebrukeres manglende kompetanse og forståelse for tolkeyrket, som truer rettssikkerheten. Tolkeyrket i Norge er i ferd med å etablere seg som et eget yrke, men det er fremdeles et stykke igjen før vi kan snakke om en fullstendig profesjonalisering. I denne artikkelen settes det søkelys på tolkeyrket som profesjon, gjennom analyse av eksempler fra opptak av tolking fra tingretten og resultater fra en spørreundersøkelse gjennomført blant tolker. Videre settes det søkelys på det nasjonale tolkeregisteret som ifølge Integrerings- og mangfoldsdirektoratet (IMDi) er «et av IMDis viktigste tiltak for å heve kvaliteten på tolking i offentlig sektor». ${ }^{2}$ Jeg stiller spørsmål om ikke dette registeret nettopp er med på å undergrave en gryende profesjonalisering av tolkeyrket i Norge og dessuten legitimere at ukvalifiserte personer tolker i norske rettssaler.

\section{Begrepsavklaring}

Rettstolk er en yrkestittel som, i motsetning til i andre land, ikke er rendyrket i Norge. Ikke engang den overordnede tittelen tolk er en beskyttet yrkestittel her til lands og brukes derfor om en person som utfører tolking (muntlig oversettelse mellom to språk) uansett denne personens utdanning og kvalifikasjoner. Tittelen statsautorisert tolk er imidlertid en beskyttet tittel, men av de tolkene som per i dag tolker i norske rettssaler er kun et mindretall statsautoriserte. ${ }^{3}$ I Norge er situasjonen slik at den utdannelsen og de kurs som finnes for tolkeyrket i dag ${ }^{4}$ forbereder tolker til tolking i offentlig sektor generelt, og tolkene tolker således innenfor helse, offentlig forvaltning og rettsvesenet. De norske tolkene er dermed ikke så spesialiserte som i andre land hvor man opererer med mer spesialiserte yrkestitler som juridisk oversetter som kan innbefatte både tolking i retten og arbeid med skriftlige oversettelser, slik det fremgår av følgende sitat fra den østerrikske oversetterviteren Franz Pöchhacker:

In many jurisdictions, what is commonly labeled 'court interpreting' includes tasks like the certified translation of documents as well as interpreting in quasi-judicial and administrative hearings. One can therefore distinguish between the broader notion of legal interpreting, or judicial interpreting, and courtroom interpreting in its specific, prototypical setting. (Pöchhacker, 2004/2007, s. 14)

2 http://www.tolkeportalen.no/no/Nyheter/Evaluering-av-Nasjonalt-tolkeregister/

3 Det er registrert behov for tolker i 109 språk i Norge. Per mai 2012 hadde Det nasjonale tolkeregisteret 1233 tolker i 65 språk, men det finnes kun statsautoriserte tolker i 23 språk. http://www.tolkeportalen.no/,

[Lesedato 23.3.2013]

4 Høgskolen i Oslo og Akershus tilbyr et EVU-kurs på 30 stp., «Tolking i offentlig sektor», samt en rekke påbyggingsemner som på sikt vil bygges ut til et fullstendig bachelorprogram.

(www.hioa.no/Studier/LU/Soknad-og-opptak).

Institutt for fremmedspråk ved Universitetet i Bergen tilbyr et emne i tolking på 15 stp.: «Tolketeori, -teknikk, -etikk og -praksis» (http://www.uib.no/emne/TOLKHF). 
Andre steder betrakter man en tolk som rettstolk selv om vedkommende også arbeider med tolking innenfor andre deler enn retten, som fengsel, advokatkontor, etc. slik det fremgår av følgende sitat fra den USA-baserte forskeren og tolken Holly Mikkelson:

Court interpreters work not only in courts of law but also in law offices, law enforcement agencies, jails and prisons, and other public agencies associated with the judiciary. (Mikkelson, 2000, s. 1)

Ettersom man i Norge ikke har en egen utdannelse som fører fram til en tittel som rettstolk og tolk heller ikke er en beskyttet yrkestittel, brukes rettstolk i denne artikkelen om en person som tolker i retten, uavhengig av hvilke kvalifikasjoner denne personen har. Likeledes brukes termen rettstolking om tolking i selve rettssalen, selv om denne termen, som vist ovenfor, noen steder også inkluderer andre typer oversettelse/tolking. Videre begrenser jeg meg til tolking mellom norsk og et fremmedspråk og kommer derfor ikke inn på tolking mellom norsk og samisk eller tegnspråk, selv om temaet selvsagt også er aktuelt for disse gruppene.

Det andre ordet i tittelen er rettssikkerhet og er her forstått som forholdet mellom individet og myndighetene slik det fremkommer fra Justisdepartementets omtale av begrepet:

Kjernen i begrepet «rettssikkerhet» er knyttet til krav om at enkeltindividet skal være beskyttet mot overgrep og vilkårlighet fra myndighetenes side, samtidig som vedkommende skal ha mulighet til à forutberegne sin rettsstilling og forsvare sine rettslige interesser. ( «Skjult informasjon - åpen kontroll», 2009, kap. 7.1)

\section{Situasjonen for rettstolking i Norge}

Det har skjedd mye positivt i Norge når det gjelder fokus på tolking generelt og på rettstolking spesielt bare det siste tiåret, og jeg vil i det følgende nevne noe av det som har skjedd, både fra myndighetens side, og når det gjelder forskning og utdanning.

I mai 2004 ble det holdt et internasjonalt symposium i Oslo med tema «Kvalitet på tolking og rettssikkerhet». Dette symposiet var organisert av Domstolsadministrasjonen, Universitetet i Oslo og Utlendingsdirektoratet (UDI) og samlet representanter fra domstolene, ansvarlige for tolkefaglige virksomheter i Norge og forskere fra inn- og utland.

På samme tid satte Justisdepartementet ned en kommisjon ledet av tingrettsdommer Kristian Jahr for å utrede situasjonen for tolking og oversettelse i norsk straffeprosess. Gruppen hadde bl.a. følgende mandat: «å foreslå nødvendige tiltak for å styrke, forbedre og effektivisere dagens regelverk og praksis for bruk av tolk og oversetting av dokumenter under behandlingen av straffesaker. Arbeidsgruppen skal fremsette konkrete forslag til regler og eventuelt komme med anbefalinger til videre arbeid/utredningsbehov på det enkelte område.» (Rett til tolk, 2005, s. 20) Arbeidsgruppen leverte i mars 2005 rapporten Rett til tolk, Tolking og oversettelse i Norsk straffeprosess. ${ }^{5}$ I rapporten foreslås en rekke regler som fastslår at det er myndighetenes oppgave å sørge for at det tilkalles tolk; at minoritetsspråklige får oversatt nødvendige dokumenter $\mathrm{i}$ forbindelse med rettssaker; regler som ivaretar tolkens funksjon og nøytralitet; endringer i gjeldende lover og forskrifter i samsvar med EMK og regelverk for domstolenes tolkeregister, som i dag er blitt til det nasjonale tolkeregisteret. Gruppen foreslo videre at det foretas lyd- eller videopptak i rettssaker for å kunne kvalitetssikre tolkingen.

5 Rapporten er tilgjengelig på Regjeringens nettsider: http://www.regjeringen.no/nb/dep/jd/dok/rapporter_planer/rapporter/2005/Rett-til-tolk.html? id $=106368$, [Lesedato 23.06.2013] 
Når det gjelder utdanning, ble det i perioden 2003-2004 gjort et stort løft gjennom det UDI-støttede prosjektet for tolkeutdanning ved fire institusjoner i Norge (Universitetet i Oslo, Høgskolen i Telemark, Høgskolen i Sør-Trøndelag og Universitetet i Bergen ${ }^{6}$ ). Tidligere hadde det vært tilbud om tolkeutdanning ved Universitetet i Oslo, men det nye opplegget var nettbasert med samlinger og kunne derfor imøtekomme de utfordringene Norge har med befolkning med tolkebehov spredt over hele landet. I dette prosjektet ble det gitt kurs på 30 studiepoeng (stp.) til mange allerede etablerte tolker, og det ble rekruttert nye. Mange tolker fikk formalisert sin kunnskap/yrkeserfaring som tolk. Til sammen var det 600 tolker på 30 forskjellige språk som deltok i dette prosjektet. Sammenlignet med tolkeutdannelser $\mathrm{i}$ andre land er $30 \mathrm{stp}$. lite og absolutt ikke tilstrekkelig for å bli en godt kvalifisert tolk, men det var en viktig begynnelse, og det var med på å gi veldig mange tolker et felles etisk og tolketeknisk ståsted og en felles forståelse for hva tolking innebærer og hvordan tolkerollen forstås i en norsk kontekst. Dette prosjektet blir nå videreført gjennom Tolkeutdanningen ved Høgskolen i Oslo og Akershus, hvor det er fokus på tolking i offentlig sektor generelt, men hvor også rettstolking tematiseres i emner i utdanningen.

Økt forståelse for hva som skjer i tolkeprosessen, gjennom forskning, er også viktige bidrag for å sette rettstolking på dagsorden, og her har Anne Birgitta Nilsen, førsteamanuensis ved Høgskolen i Oslo og Akershus, gitt et viktig bidrag gjennom sin doktoravhandling om tolking i norsk rettsvesen, som er basert på en rettssak hvor det ble tolket mellom arabisk og norsk (Nilsen, 2005). Avhandlingen har fătt mye presseomtale, og Nilsen har også skrevet en rekke kronikker som har vært med på å sette fokus på tolking i retten.

Et annet forskningsprosjekt er professor Hanne Skaaden og førsteamanuensis Tatjana R. Felberg fra Høgskolen i Oslo og Akershus sin studie av en rettssak hvor de bl.a. studerer samspillet mellom aktørene i retten: Profesjonalitet og språklige nyanser i tolkede vitneeksaminasjoner. ${ }^{7}$

Artikkelforfatteren gjennomførte selv et mindre forskningsprosjekt i 2008/2009 med opptak av tolkede rettssaker og fengslingsmøter som eksemplene i denne artikkelen er hentet fra. Jeg vil også nevne at Patrick Kermit og Berit Berg ved Nordlandsforskning og NTNU har et forskningsprosjekt som undersøker rettssikkerheten til døve og hørselshemmede i straffesaker.

Opprettelsen av Norsk Tolkeforening ${ }^{8}$ i 2004 har også bidratt til å fremme tolkeyrket, og lederen John Richard Stokbak Sciabà er ofte i media for å fremme tolkerelaterte saker. Første hovedmål i foreningens prinsipprogram er som følger: «Tolking må bli en profesjon med beskyttet tittel med definerte kompetansekriterier og et normert utdanningsløp».

Som vist ovenfor har konferanser, utredninger, utdanning, forskning og opprettelse av fagog interesseforeningen vært med på å sette fokus på tolkeyrket generelt og rettstolking spesielt, det siste tiåret. For oss som har fulgt tolkeyrket siden slutten av 1980-tallet, er det helt klart en mye bedre situasjon i dag, og faktisk enda bedre enn det var for bare ti år siden. Men vi er likevel langt fra en situasjon hvor rettssikkerheten i tolkede rettssaker er ivaretatt på en tilfredsstillende måte og hvor tolkeyrket er en profesjon på linje med de andre yrkesutøverne som er til stede i en rettssak.

6 http://www.tolkeportalen.no/no/For-tolker/Utdanning/Tolkeutdanning---historikk/, [Lesedato 23.03.2013]

7 Et sammendrag av prosjektet finnes her:

https://www.cristin.no/as/WebObjects/cristin.woa/wa/presentasjonVis?pres=305713\&type=PROSJEKT, [Lesedato 23.03.2013]

8 http://www.tolkeforeningen.no/om ntf.php, [Lesedato 30.8.2014] 
På et seminar ved Høgskolen i Sør-Trøndelag ${ }^{9}$ høsten 2011 konkluderer Nilsen sitt innlegg med at både tolkebrukernes og tolkenes mangel på kompetanse er med på å true rettssikkerheten (Nilsen, 2012). Det har vært mange oppslag i pressen om dårlige tolker og feil som er blitt begått, men ofte blir oppslagene bare historier som fokuserer på tolkens manglende kvalifikasjoner. Det er også viktig å påpeke betingelsene tolkene arbeider under. I en kronikk i Dagbladet i 2011 gir Nilsen et godt eksempel på hvordan flinke tolker blir forhindret i å utføre sine arbeidsoppgaver fordi forventningene fra aktørene i rettssaken ikke er forenelige med tolkens arbeidssituasjon:

I en rettssak ble det benyttet en rutinert statsautorisert tolk. Fra dette oppdraget kunne tolken fortelle at dommeren bare svært motvillig gikk med på å gi henne en pause, som var nødvendig for å opprettholde kvaliteten på tolkingen. Da tolken kom tilbake etter pausen, var dommeren allerede i gang med å lese opp kjennelsen. Dommeren ba da tolken tre inn i siste del av opplesningen. Da denne opplesningen var ferdig, gjorde tiltalte dommeren oppmerksom på at han ikke hadde fătt med seg mer enn siste del av kjennelsen. Dommeren skyldte på tolken og fraskrev seg ansvaret for kommunikasjonen i egen rettssal. (Nilsen, 2011)

\section{Norsk tolkeregister}

Et av tiltakene nevnt i rapporten fra arbeidsgruppen ledet av tingrettsdommer Jahr er opprettelsen av Norsk tolkeregister, og i det følgende vil jeg kort presentere dette. I følge IMDi (Integrerings og Mangfoldsdirektoratet) er Norsk tolkeregister «et av IMDis viktigste tiltak for å heve kvaliteten på tolking i offentlig sektor.»10 ${ }^{10}$ Registeret er tilgjengelig på Internett ${ }^{11}$, det er søkbart (språk, kjønn, fylke og kvalifikasjonskategori) og de registrerte tolkene er inndelt i følgende fem kategorier:

\section{Nivå 1: Tolker med statsautorisasjon og tolkeutdanning}

Statsautoriserte tolker med bevilling fra Kommunal- og regional-departementet (KRD) eller Integrerings- og mangfoldsdirektoratet (IMDi) og minst 30 studiepoeng/10 vekttall i tolking fra universitet og/eller høgskole.

\section{Nivå 2: Tolker med statsautorisasjon}

Statsautoriserte tolker med bevilling fra Kommunal- og regionaldepartementet (KRD) eller Integrerings- og mangfoldsdirektoratet (IMDi).

\section{Nivå 3: Tolker med tolkeutdanning}

Tolker med minst 30 studiepoeng og/eller 10 vekttall i tolking fra universitet og/eller høgskole.

\section{Nivå 4: Oversettere med grunnleggende tolkeopplæring}

Statsautoriserte translatører og/eller fagoversettere som har kurset i Tolkens ansvarsområde (TAO).

\section{Nivå 5: Personer med bestått tospråklig test og grunnleggende tolkeopplæring}

9https://docs.google.com/presentation/d/1vG0pbapQ3By2n7qEPMTv6poROof5iVoghoh82012Qfo/edit? pli=1\#slide=id.i80, [Lesedato 30.12.2013]

10http://www.tolkeportalen.no/no/Nyheter/Evaluering-av-Nasjonalt-tolkeregister/, [Lesedato23.03.2013]

11Registeret er tilgjengelig på Tolkeportalen.no, [Lesedato 23.03.2013] 
Personer som har tilfredsstillende resultat på Tospråklig sjekk for potensielle tolker (ToSPoT), samt kurs i Tolkens ansvarsområde (TAO) $)^{12}$

Som vi ser av listen utgjør gruppen statsautoriserte tolker (som har gjennomgått en krevende praktisk og teoretisk eksamen) de øverste to nivåene. Imidlertid er gruppen delt i to, og de som har utdanning er satt i øverste kategori. På denne måten fremheves utdanning som en viktig komponent i profesjonaliseringen. Det er ikke bare erfaring og en autorisasjonseksamen som gjør en profesjon, men også utdanning. Dette samsvarer med sosiologen Thomas Brantes definisjon av en profesjon hvor forskningsbasert kunnskap knyttes direkte til definisjonen:

Occupations conducting interventions derived from scientific knowledge of mechanisms, structures, and contexts. (Brante, 2001, s. 17)

På nivå 3 finner vi tolker som har gjennomgått tolkeutdanning på minst 30 stp. mens $i$ kategori 4 og 5 brukes ikke lenger betegnelsen tolker, men derimot oversettere (nivå 4) og personer (nivå 5). Nivå 4 omfatter statsautoriserte translatører som heller ikke har en fullverdig utdannelse i Norge, men en omfattende eksamen som fører til autorisasjon. Fagoversettere har en treårig utdannelse som tidligere ble gitt på Universitetet i Agder (den gang Høgskolen i Agder). Begge disse gruppene har prøvde kunnskaper på høyt nivå i både norsk og tolkespråket, men er utdannet til å jobbe med skriftlige oversettelser og ikke muntlig tolking. Forskjellen mellom oversettelse og tolking finner vi igjen i forskjellen mellom skriftlig og muntlig kommunikasjon. Den muntlige kommunikasjonen er lineær og synkron, og foregår som oftest på samme sted og til samme tid, mens den skriftlige er asynkron og ikke lineær og vi kan gå tilbake og forandre noe vi har skrevet før teksten er endelig. Tidspresset er større for tolken som må oversette i sanntid og følge de andre aktørenes rytmer med få muligheter til å konsultere noen eller til å slå opp ord i ordbøker eller andre hjelpemidler og verktøy som er en naturlig del av en oversetters hverdag. Av denne grunn er det ikke alle oversettere som egner seg som tolker og omvendt. Det er derfor ikke urimelig at en utdannet oversetter eller en statsautorisert translatør må ta 30 studiepoeng i tolking for å komme på et høyere nivå i registeret. I den siste kategorien, nivå 5, er yrkesbetegnelsene tatt bort og de som er registrert i denne kategorien kalles bare personer. Kriteriet for å komme i denne kategorien er å ha tatt en glosetest (ToSPoT) og et kort kurs i tolkens ansvarsområde (TAO). På Tolkeportalen heter det at «Ved behov for tolking bør tolkene oppført i kategoriene 1, 2 og 3 bli prioritert.» Det er de som i registeret er oppført med yrkesbetegnelsen tolk. Statsautoriserte translatører eller fagoversettere med kurs i Tolkens Ansvarsområder er plassert på nivå 4 og er derfor ikke blant de som anbefales som tolker uten at de i tillegg har tatt tolkeutdanning. Avstanden mellom nivå 4 og nivå 5 må imidlertid sies å være ganske stor når det gjelder språkkunnskaper som er det de er testet for. Statsautoriserte translatører er blitt testet i skriftlige språkkunnskaper i begge språk, mens de som plasseres på nivå 5 ikke er blitt testet i andre språklige kvalifikasjoner enn å ha bestått det jeg vil kalle en avansert gloseprøve inkludert noen termer i kontekst. De kan selvsagt ha meget gode språkkunnskaper, men det språklige kriteriet for å komme inn i denne kategorien er kun testen ToSPot. Begge gruppene må også ha et kort kurs i Tolkens Ansvarsområde for å bli oppført i registeret, men de er ikke testet i praktiske tolkeferdigheter. For noen språk finnes det ikke tolker på nivå 1 til 3. Det kan skyldes at det enda ikke er tilbudt tolkeutdanning i disse språkene, og blant de registrerte kan det finnes personer som er høyt motivert for tolkeyrket, og som vil ta utdanning så snart dette er mulig.

12 Omtale av ToSPoT og TAO:http://www.tolkeportalen.no/no/For-tolker/Test-og-kurs/, [Lesedato 23.03.2013] 
Forskjellen mellom tolkene på nivå 1 til 3 og oversetterne/personene på nivå 4 og 5 viser seg også i forhold til tolkenes interesseorganisasjon, Tolkeforeningen, der tolker som er oppført på nivå 1 til 3 umiddelbart får medlemskap i foreningen, men tolker på nivå 4 eller 5 må ha tolkepraksis på 600 timer for å bli medlem. På den måten knyttes ikke personer på nivå 4 og 5 til yrkesorganisasjonen før de har hatt 600 timers tolkepraksis. Utdanning og erfaring er således ansett som profesjonaliserende.

\section{Tolkens synlighet}

Et annet viktig aspekt ved profesjonalisering er tolkens rolle i rettssalen. $\AA$ inneha et yrke er å være synlig som profesjonsutøver for andre aktører i arbeidssituasjonen der yrket utføres. Dersom tolken ikke selv opplever seg selv som er en synlig aktør på lik linje med de andre aktørene i rettssalen, så er ikke tolkeyrket ansett som en profesjon. $\AA$ være en synlig profesjonsutøver medfører også å kunne gi beskjed dersom noe eller noen hindrer en i $a$ utføre sitt yrke på en optimal måte. I en forskningsrapport fra Claudia Angelleli slår hun fast at det er lettere å lære opp tolkene til å være usynlige, enn til å lære dem å ta ansvar for den rollen de har som en synlig deltaker i kommunikasjonssituasjonen.

From the perspective of the pedagogy of interpreting, one may see that teaching students to be invisible is certain more feasible than teaching them how to manage their role responsibly as a third interlocutor. Could it be that it is simpler to prescribe that "parties should communicate as if the interpreter were not there" than to attempt to explore all possibilities that may arise when the interpreter participates in the interaction?" (Angelleli, 2004, s. 90)

Dersom tolkene blir oppfattet (og oppfattet seg selv) som synlige aktører i retten og likeverdige med de andre aktørene, vil alle aktørene sammen kunne legge forholdene til rette for at tolkene skal kunne utføre sitt arbeid til beste for alle parter.

\section{Undersøkelser og metoder}

Med bakgrunn i gjennomgangen av tolkeregisteret og diskusjonen om tolkens synlighet vil jeg i det følgende vise resultater fra to undersøkelser jeg har gjennomført, for på den ene siden å se hvordan tolking i rettssalen kan true eller fremme rettssikkerheten, og på den andre siden å undersøke hvordan tolkene selv opplever sin egen tilstedeværelse og arbeidssituasjon i rettssalen.

\section{Opptak av autentiske rettsmøter}

I $2008 / 2009$ foretok jeg en undersøkelse av tolkede rettssaker og fengslingsmøter. Jeg fikk først en generell tillatelse til å spille inn rettssaker og fengslingsmøter ved en av landets tingretter i 2008/2009. I forkant av de aktuelle rettssakene ble alle parter forespurt og ga sitt samtykke til opptak, og opptakene ble deretter gjennomført, transkribert og anonymisert. ${ }^{13}$ Opptakene ble gjort på minidiskopptakere som var plassert forskjellige steder i rettssalen. Artikkelforfatteren har selv transkribert den norske talen, en med fremmedspråket som morsmål uten god kjennskap til norsk har transkribert og anonymisert den fremmedspråklige teksten, en oversetter i det aktuelle språket har oversatt den transkriberte teksten til norsk og en morsmålsbruker har kontrollert den transkriberte og oversatte teksten mot den innspilte talen. Prosessen med à transkribere og oversette

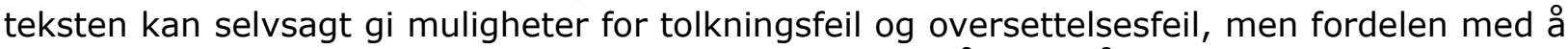
ha flere aktører involvert i denne prosessen er at man på den måten reduserer mulighetene

13 Prosjektet ble registrert hos personvernombudet med nummer 21278 
for rent subjektive tolkinger. Målet med denne undersøkelsen var å få tilgang til autentisk materiale for å kunne beskrive de prosessene som foregår i en tolket rettssak.

\section{Spørreundersøkelse}

For å undersøke hvordan tolkene selv opplever det å tolke i retten, gjennomførte jeg en spørreundersøkelse i 2009. ${ }^{14}$ Undersøkelsen tok utgangspunkt i tolkene som var oppført i Tolkeregisteret, og jeg valgte å begrense undersøkelsen til tolker i åtte språk; fire europeiske (dog ikke kun begrenset til Europa) og fire ikke-europeiske. Jeg valgte også ut språk som hadde mellom 35 og 55 oppførte tolker i registeret og som var spredt på forskjellige nivåer. I alle gruppene var det tolker på nivå 1, 3 og 5, men ikke alltid på nivå 2 og 4. Det var til sammen 392 tolker i denne gruppen, og de ble kontaktet via epostadressen de var oppført med i registeret. Flere manglet e-postadresse, eller adressen var feil, og det totale antallet medlemmer som ble kontaktet var derfor 292. Av disse deltok 96 i undersøkelsen, og 92 svarte på alle spørsmålene. Undersøkelsen ble gjennomført ved hjelp av det web-baserte programmet for spørreundersøkelser, Refleks. Målet med denne undersøkelsen var å finne ut hvordan tolkene opplevde det å tolke i en rettssak, spesielt med fokus på om de følte seg likeverdige de andre aktørene i rettssaken og om de opplevde å være synlige yrkesutøvere for disse.

\section{Analyse av opptak av rettsmøter}

Med eksempler fra det autentiske materiale jeg spilte inn i 2008/2009, vil jeg i det følgende diskutere hvordan tolkens kvalifikasjoner i henhold til nivå i tolkeregisteret kan være med på å true eller fremme rettssikkerheten i norske rettssaler.

Den første saken jeg vil trekke frem viser hvordan bruk av en ikke kvalifisert tolk fører til feiloversettelser og misforståelser og på den måten bidrar til å true den tiltaltes rettssikkerhet.

Det aktuelle utdraget er fra et fengslingsmøte $i$ en narkotikasak, og min tolking ${ }^{15}$ av konteksten og aktørenes roller er som følger: For den siktede er fengslingsmøtet et avbrekk fra lang varetektisolasjon, og den siktede ønsker å få ført sin sak der og da. Aktor ønsker à få møtet gjennomført raskt, man hadde glemt å bestille tolk, og møtet blir derfor utsatt to ganger samme dag. Forsvareren er siktedes fjerde forsvarer og har ikke vært til stede ved tidligere fengslingsmøter. Personen som fremstår som tolk for aktørene i rettssaken var i tolkeregisteret oppført under nivå 5, men omtales likevel i det følgende som tolken. Tolken har tolket for siktede før, og har denne dagen steppet inn på kort varsel, fordi det ikke var forhåndsbestilt tolk. Dommeren skal avgjøre aktors begjæring om 12 ukers ny varetekt (resultatet blir fire uker). Nedenfor gjengis fire eksempler fra det ovennevnte fengslingsmøte. I eksemplene er all tale transkribert fra tale til norsk skriftspråk, og det er brukt tegnsetting for skriftspråk for å gjøre lesingen lettere, mens tolkens uidiomatiske norsk ikke er korrigert. I kolonnen til venstre står oversettelsen av den fremmedspråklige talen slik den fremkommer for den siktende, og i kolonnen til høyre står teksten slik den fremkommer på norsk for retten: ${ }^{16}$

14 Undersøkelsen ble registrert hos personvernombudet, NSD og ble gjennomført i henhold til gjeldende etiske retningslinjer.

15 Min tolking er basert på observasjon og feltnotater tatt før og under rettsmøtet.

16 Denne måten å presentere eksemplene på er hentet fra Nilsen (2005). 
Eks. 1 - Tolken er mindre spesifikk enn den tiltalte: 'heroin' blir oversatt med 'saken', 'den' eller 'det som' (uthevingen er min).

Siktede:

Nye ting. Si det til ham/henne ${ }^{17}$ at det ikke reises sak for min opprinnelige sak. Det som er reist sak om nå tilhører andre personer, som jeg verken kjenner,eller har noen tilknytting til heroinsforbrytelse.

Denne heroinen har ikke noe med meg å gjøre. Denne heroinen de har tiltalt meg for, er det politiet som har funnet.

Si det til ham/henne at denne heroinen de har funnet, viste seg verken tilhører meg eller hadde mitt fingeravtrykk på. Jeg har ingen forbindelse med denne heroinen.

\section{Tolken (slik saken framstilles for retten):}

Jeg ser at de tiltalepunktene som de har lest mot meg det er andre ting det er noe som gjelder om andre personer ikke om meg jeg har ikke noe med den saken å gjøre.

Disse har ikke noe med meg å gjøre, det som politiet har funnet hos eller ...

Men det som politiet har funnet tilhører ikke meg og de har ikke funnet mitt fingeravtrykk en gang

(resten utelatt)

I eksempel 1 ser vi at tolken gjentatte ganger er mindre spesifikk en det den siktede er. Siktede sier ordet 'heroin' fem ganger, mens tolken ikke bruker ordet en eneste gang. Det kan nesten virke som om det er vanskelig for tolken å ta ordet 'heroin' i sin munn.

\section{Eks. 2 - Tolken nøytraliserer og modifiserer det den siktede sier (uthevingen er min):}

\section{Siktede:}

Jeg er bare den personen som har lidd i isolatet seks måneder (...)

Forsvarer:

Hvordan er formen din nå etter den varetektstiden som har vært

\section{Siktede:}

Virkelig så kan jeg ikke stå på mine bein. Jeg kan ikke se med mine øyne [dårlig syn]. Jeg ble utsatt for veldig sterk tortur.

Jeg ble utsatt for en streng isolasjon (...)[taler samtidig med tolken]
Tolken:

Jeg har sittet nå $\mathbf{i}$ isolat $\mathbf{i}$ seks måneder (...)

\section{Hvordan er din situasjon - fysisk}

Jeg har fått dårlig ... er blitt dårligere i synet og har smerter eller problemer i føttene eller i beinet

Jeg har sittet $\mathrm{i}$ isolasjon $\mathrm{i}$ lang tid og føler meg dårlig sånn helsemessig

17 Det aktuelle fremmedspråket skiller ikke mellom kjønn i personlige pronomen. 
I dette eksemplet ser vi at tolken modifiserer og nøytraliserer siktedes uttrykksmåte og situasjonen hans fremstår ikke på samme måte som han selv synes å ville fremstille den. Videre ser vi, både $\mathrm{i}$ eksempel 1 og 2, at det vokabularet som tolken bruker $\mathrm{i}$ sin oversettelse gir inntrykk av at den tiltalte behersker rettsterminologi og at han har et mer avansert språk enn det han egentlig har (eks. 'tiltalepunkter' i eksempel 1 og 'helsemessig' i eksempel 2).

\section{Eks. 3 - Tolken pynter på siktedes språklige fremstilling}

Siktede:

Si det til ham/henne ingen vet noe om dette - dommeren selv vet ikke om min sak - kun vet hva som står i politiets papirer. Det er ikke slik at politiet har dem.
Tolken

Jeg ser at retten er orientert med saken i følge de eh tiltalepunktene som eh statsadvokaten

Retten leste mot meg. De har ikke hørt saken fra min side eller min versjon.

Dette eksempelet viser bl.a. at tolken bruker en mer spesifikk juridisk terminologi enn den siktede, som for eksempel: 'retten', 'tiltalepunkt' og 'statsadvokaten'. Den siktede fremstår derved som en person som er kjent med rettsterminologi. Ifølge kommentarer fra de som har transkribert, oversatt og korrekturlest tekstene viser den siktedes språk en person med en sosiolekt som tilsier at vedkommende kommer fra et lavere sosialt lag. På denne måten får retten et annet inntrykk av hvilken person de har med å gjøre.

\section{Eks. 4 - Tolken forsterker tiltaltes frustrasjon og siktedes anklager mot advokatene}

Siktede:-

Det ble skiftet fire advokater for meg.

De bare lover meg.

(sukker)

De sier til meg bare vent.

(...)

(Siktede vil anke)

Samtale mellom dommer og forsvarer:

Dommer [til forsvarer]: Støtteskriv?

Forsvarer: ja jeg sitter her og ser på det jeg har et fengslingsmøte her i morgen også ehm kan jeg si at det blir ettersendt politi og lagmannsrett innen kl. 15 i morgen. Găr det bra?
Tolken (slik saken framstilles for retten): Han er min fjerde advokat jeg har måttet ski... bytte fire advokater fordi jeg ser at det er bare tomme løfter som de gir

Samtalen slik den oversettes til siktede:

Tolk: --

Tolk: Besøket på fengselet er i morgen

Han sier vi kan [vente] til i morgen kl 15.00 
I eksempel 4 ser vi først at siktede uttrykker sin frustrasjon over advokatene fordi han opplever at de bare ber ham vente. Det fremgår videre av samtalen (ikke transkribert her) at siktede ønsker å anke avgjørelsen. I den forbindelse finner det sted en samtale mellom dommer og forsvarer hvor sistnevnte lurer på når han kan få tid til å sende inn støtteskriv for anken. Advokaten har et nytt fengslingsmøte dagen etterpå og spør om det går bra å sende det innen kl. 15. Dette blir oversatt av tolken på en måte som kan gi siktede inntrykk av at han vil få besøk av advokaten i fengselet dagen etterpå kl. 15.00. De andre aktørene i retten har ingen mulighet for å kontrollere hva tolken sier, men må bare stole på at vedkommende er kvalifisert og gjør en god jobb som tolk. Ovennevnte eksempler viser én representant for nivå 5 i tolkeregisteret og viser at tolken ikke er verken språklig eller tolkefaglig kvalifisert til å bære det ansvaret det er å tolke en rettssak. Det finnes imidlertid godt kvalifiserte tolker på alle nivåer for språket det dreier seg om i denne saken.

Like mye som ukvalifiserte tolker truer rettssikkerheten, fremmer kvalifiserte tolker denne, og i følgende skal vi se noen eksempler på hvordan en kvalifisert tolk takler utfordringer i rettssalen og hvordan kompetanse hos tolkebrukerne er med på å legge arbeidsforholdene til rette for tolken. Følgende er utdrag fra en rettssak i tingretten og tolken er på nivå 1, det vil si statsautorisert tolk med utdanning. Talen er transkribert til standard norsk skriftspråk for å lette lesingen.

\section{Eks. 5. - Dommeren kommuniserer med tolken om selve tolke-situasjonen.}

Dommer: Før vi går videre, har du tolket tidligere?

Tolk: Ja, det har jeg. Ja.

Dommer: Og jeg hører at du kan simultantolke?

Tolk: Ja.

Dommer: Supert, da bare gir du beskjed hvis vi skal vente litt eller det er noe du må ha gjentatt.

Tolk: Ja, det er fint.

Her viser dommeren forståelse for tolkens arbeidssituasjon og kommuniserer direkte med tolken.

\section{Eks. 6 - Dommeren minner de andre aktørene om å ta hensyn til tolken}

Dommer: Snakker du kanskje litt roligere, det kanskje går litt fort for tolken.

Aktor: Ja. Tolken må bare gi beskjed

Tolk: Ja, ja.

Videre ser vi av eksempel 6 at dommeren tar ansvar for at de andre aktørene også skal legge forholdene til rette for tolken. 


\section{Eks. 7 - Tolkens strategier når hun ikke får med seg alt det som blir sagt.}

Dommer: Men da får jeg ta opp et spørsmål som retten da anser relevant, det vil være bortkastet tid hvis vi sitter her til klokken er fire for så å avlutte uten å da få dette vitnet. Sånn at jeg lurer på hvor stor betydning du mener at det har for det tilfellet at vi ikke făr tak i henne ... i dag.

Forsvarer: Ja, det er jo alltid litt vanskelig selvfølgelig å avgjøre slik i forkant.

Dommer: Fordi vi ikke kunne begynne på prosedyrer, det ville jo vært et alternativ at vi kunne delt opp men det ville ikke være et alternativ for da ville vi heller ikke kunne få avsluttet skyldspørsmålet.

Forsvarer: Nei, men jeg er nok ganske sikker på at vi skal få kontakt med henne i dag.

Tolk: Unnskyld? Hva var din innvending... Fordi... Det gikk litt fort her tolken fikk ikke alt med seg.

Dommer: Jo, hvis dette vitnet er veldig relevant så vil det kunne by på et problem hvis vi ikke får tak i vitnet og det er ikke et alternativ å dele forhandlingene mellom skyld- og straffespørsmålet ...

I eks. 7 ser vi at det foregår en samtale mellom dommer og forsvarer som tolken ikke helt klarer å få med seg, og at dommeren oppsummerer innholdet på tolkens oppfordring. Da kan tolken tolke dommerens oppsummering og unngår derved feiltolking som kunne skjedd dersom hun selv skulle oppsummert. Som vi ser har både dommer og advokater forståelse for tolkens arbeidssituasjon i denne rettssaken og hjelper til og legger forholdene til rette slik at både tolken og de selv kan utføre sine arbeidsoppgaver i retten. Det er viktig å huske på at tolken er like mye til stede for at dommer, aktor og forsvarsadvokatene skal kunne gjøre sin jobb som for at den tiltalte eller vitnene skal få fortalt sin historie, forstå hva som skjer og få fremmet sin sak.

\section{Tolker eller tospråklige hjelpere?}

Eksemplene som er diskutert ovenfor viser to enkeltstående hendelser fra tingretten og er ikke nødvendigvis representative for all den tolkingen som foregår i norske rettssaler. Eksemplene illustrerer likevel to autentiske situasjoner hvor den ene tolken er høyt kompetent og den andre ikke er det. Målet med en profesjonalisering av tolkeyrket på sikt må være at betegnelsen tolk kun brukes om personer som gjennom en yrkesutdanning og et profesjonsfellesskap har tilegnet seg den kunnskapen og de ferdighetene dette yrket krever.

I den tidligere nevnte kronikken i Dagbladet (Nilsen, 2011) trekker Nilsen en skillelinje mellom, på den ene siden, tolker (personer med tolkeutdanning og/eller autorisasjon, altså nivå 1, 2 og 3) og, på den annen side, det hun kaller tospråklige hjelpere (Nilsen, 2011). Dette skillet er imidlertid ikke like tydelig for den som går inn i registeret og søker opp en tolk fra sitt distrikt på sitt språk. Kanskje burde man begrense selve registeret til de som betegnes med yrkestittelen tolk og på den måten gjøre det mer attraktivt for oversetterne og personene i kategori 4 og 5 à ta den utdanningen som tilbys ved HiOA. Et åpenbart problem ved en slik løsning er at det trengs tolker i langt flere språk enn det er gjennomført utdanning i. Men dersom man vil arbeide mot en profesjonalisering av tolkeyrket, er det nødvendig å utelukke de som åpenbart ikke er kvalifiserte. En løsning på dette kunne være at nivå 5 kun eksisterte for de språk det ikke har vært gitt tolkeutdanning i. Når 
tolkeutdanningen har vært gjennomført i det aktuelle språket kunne språket, og derved ukvalifiserte tolker, slettes fra nivå 5 . Dette ville borget for kvalitet på en helt annen måte enn i dag. For brukerne av registeret, offentlig ansatte som skal bestille tolk, kan det være vanskelig skille mellom nivåene, og ikke alle kjenner godt nok til kriteriene. På nettsidene til Universitetet i Troms $\varnothing$ kan vi lese følgende under universitetets beskrivelse av yrket Tolk:

Det er flere måter å bli tolk på. Du kan være statsautorisert tolk, ta tolkeutdanning eller bestå en enkel skriftlig prøve (ToSPoT) og et introduksjonskurs om tolkens ansvarsområde. ${ }^{18}$

Dette er et eksempel på at tolkeregisterets fem nivåer betraktes som en reell inndeling av tolker, og denne teksten gir således en feilveiledning til studenter som ønsker å utdanne seg i dette yrket.

\section{Analyser av resultatene fra spørreundersøkelsen}

Som vi har sett er det viktig at tolkene er så profesjonaliserte at de kan utføre tolking på et høyt nivå og intervenere når noe eller noen hindrer dem i å utføre sitt arbeid på en fullverdig måte. De må altså være synlige aktører i rettssalen, slik tolken på nivå 1 i eksempel 5-7 ovenfor helt tydelig var synlig for de andre aktørene i retten og ble oppfordret til å gi beskjed dersom det var noe som gjorde hennes arbeidssituasjon vanskelig.

Den gjennomførte spørreundersøkelsen viser hvordan tolkene selv opplever sin situasjon i rettssalen. Som nevnt var åtte språk valgt ut, med 96 respondenter totalt og 92 av disse som svarte på alle spørsmålene. Respondentene fordeler seg på språkene som følger:

\begin{tabular}{|c|c|c|c|}
\hline & Svaralternativer & Antall & $\%$ \\
\hline$=$ & 1. Arabisk & 15 & $15.63 \%$ \\
\hline$=$ & 2. Engelsk & 19 & $19.79 \%$ \\
\hline$=$ & 3. Fransk & 7 & $7.29 \%$ \\
\hline$=$ & 4. Persisk & 11 & $11.46 \%$ \\
\hline$=$ & 5. Polsk & 17 & $17.71 \%$ \\
\hline$=$ & 6. Somali & 9 & $9.38 \%$ \\
\hline$=$ & 7. Sorani & 10 & $10.42 \%$ \\
\hline$=$ & 8. Spansk & 8 & $8.33 \%$ \\
\hline
\end{tabular}

Figur 1: Respondenter fordelt på språk.

Når det gjelder antall tolker per nivå i Tolkeregisteret, er fordelingen som følger: nivå 1 21, nivå $2-12$, nivå $3-44$, nivå $4-4$, nivå $5-15$. Krysstabulering av språk og nivå vises i figur 2, og der kan vi se at det kun er engelsktolker som er representert på alle fem nivå̀ene, og at de andre språkene er representert med minst tre nivåer. To av språkene (fransk og somalisk) har ingen respondenter fra nivå 1, mens alle språkene er representert i nivå 5. 


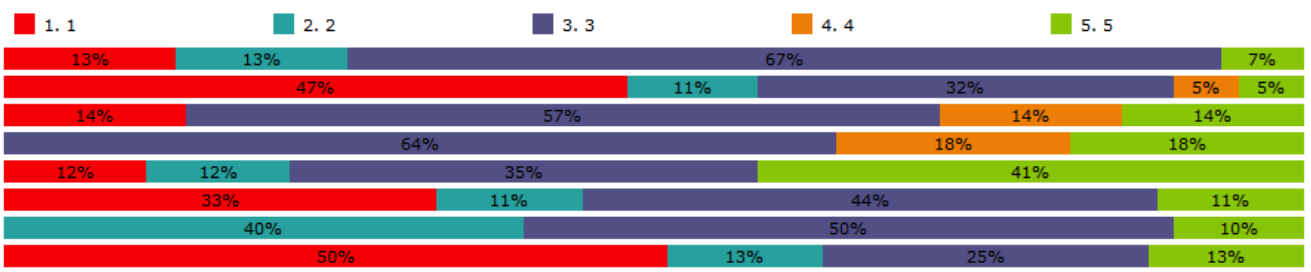

Figur 2: Krysstabulering av respondentenes språk og nivå i Tolkeportalen.

Når det gjelder erfaringer fra rettssalen viser figur 3 at det kun er tolker på nivå 4 og 5 som aldri har tolket i retten. Oversettere uten tolkeutdanning (nivå 4) er de som tolker sjeldnest i retten. De andre nivåene fordeler seg slik intensjonen med Tolkeportalen har vært: Tolker på nivå 1 tolker mest og tolker på nivå 5 er de som har færrest oppdrag.

\begin{tabular}{|c|c|c|c|c|}
\hline $\begin{array}{l}\text { 1. Har aldri } \\
\text { tolket i retten }\end{array}$ & $\begin{array}{l}\text { 2. Har kun } \\
\text { tolket } 1-2 \\
\text { ganger }\end{array}$ & $\begin{array}{l}\text { 3. 1-2 ganger } \\
\text { i året }\end{array}$ & $\begin{array}{l}\text { 4. 3-10 } \\
\text { ganger i året }\end{array}$ & $\begin{array}{l}\text { 5. Mer enn ti } \\
\text { ganger i året }\end{array}$ \\
\hline
\end{tabular}

1

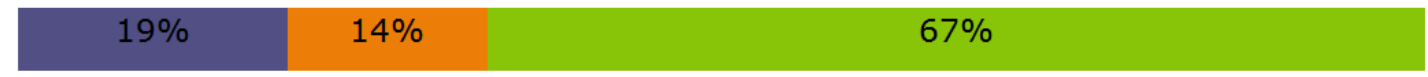

2

$\begin{array}{llll}25 \% & 8 \% & 25 \% & 42 \%\end{array}$

3

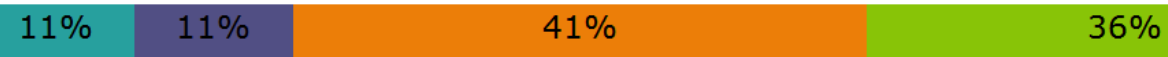

4

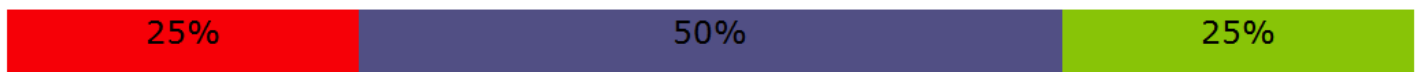

5

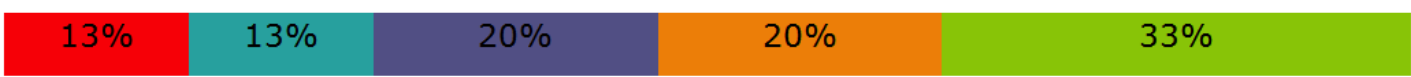

Figur 3: Krysstabulering av respondentenes tolkeerfaring i retten og nivå i Tolkeportalen.

Som vi har sett er de 96 respondentene i undersøkelsen fordelt på åtte språk og fem nivåer, og over halvparten tolker minst tre ganger i året i retten. Utvalget kan således sies å være representativt for norske tolker som tolket i norske rettssaler i 2009 . Et av målene med undersøkelsen var å kartlegge hvordan tolkene oppfattet sin egen rolle $\mathrm{i}$ retten og deres opplevelse av egen synlighet. På direkte spørsmål om de føler seg synlige i rettssalen svarer 49 prosent ja, mens henholdsvis 22 og 23 prosent svarer nei og vet ikke. Dersom tolkene føler seg synlige i rettssalen, bør de være i stand til å takle noen utfordringer som gjør at de må gå ut av sin rolle som «mekanisk oversetter» og være $\mathrm{i}$ stand til å stoppe rettssaken for à spørre når det er noe de ikke forstår. På spørsmål om de er enige i at de kan spørre når det er noe de ikke forstår, svarer de fleste positivt, og når jeg krysser dette spørsmålet med nivå, er resultatet som følger: 79 - 95 prosent av tolkene på nivå 1, 2, 3 og 5 svarer at de er enig eller helt enig i dette. 100 prosent av tolkene på 
nivå 4, altså oversettere uten tolkeutdanning, svarer imidlertid at de er uenig eller helt uenig i dette. De fleste respondentene er altså enige i at de kan spørre og avbryte om det er noe de ikke forstår, og ut fra det kan vi slutte at de til en viss grad føler seg synlige og til stede som en av aktørene med talerett i rettssalen. En av kommentarene fra respondentene på dette spørsmålet var som følger: «Er dette spørsmålet myntet på profesjonelle tolker???» og er en interessant kommentar fordi denne tolken ser på det som en integrert del av profesjonen å kunne være synlig i retten. Dersom tolkene føler seg synlige, vil man også kunne anta at de opplever at de andre aktørene i rettssalen betrakter dem som likeverdige profesjonelle. Som vi så fra rettssaken i eksempelet over tok dommer og advokat hensyn til tolken, kanskje spesielt etter initiativ fra dommeren. Jeg stilte ett spørsmål for hver av de forskjellige aktørene i rettssalen, og spørsmålene var formulert som følger: «Hvordan opplever du forholdet mellom deg selv som utøver av tolkeyrket og de andre aktørene i retten? Dommeren ${ }^{19}$ ser på tolkeyrket som et likeverdig yrke, på linje med dommer, advokat og sakkyndige.» Resultatene vises i tabell 1:

\begin{tabular}{|l|l|l|l|l|}
\hline Aktør & $\begin{array}{l}\text { Helt } \\
\text { enig }\end{array}$ & Enig & Uenig & Helt uenig \\
\hline Dommer & 12 & 43 & 28 & 9 \\
\hline Forsvarer & 11 & 41 & 38 & 2 \\
\hline Aktor & 9 & 34 & 44 & 5 \\
\hline $\begin{array}{l}\text { Tiltalte/ } \\
\text { siktede/vitner }\end{array}$ & 6 & 34 & 46 & 6 \\
\hline
\end{tabular}

Tabell 1: Tolkenes opplevelse av om de andre aktørene i rettssalen ser på dem som profesjonelle.

Som vi ser av tabell 1 mener ca. halvparten at de andre aktørene betrakter dem som likeverdige profesjonsutøvere, men få er helt enig. Det er også en forskjell mellom aktørene. De fleste opplever dommer og forsvarer som mer positive til tolkeprofesjonen enn aktor og den tiltalte/siktede eller vitner. Når dette krysstabuleres med nivå, er det respondenter på nivå 4 som er minst enig i at de andre aktørene ser på tolkeyrket som likeverdig. Når det gjelder tolkenes opplevelse av sin egen profesjon, svarer 71 prosent ja på at de selv anser tolkeyrket som likeverdig de andre aktørenes yrker, mens 15 prosent svarer nei og sju prosent vet ikke. 66 prosent av tolkene på nivå 4 svarer nei eller vet ikke på dette spørsmålet og er således de som har en minst positiv opplevelse av t o I k e profe s jo n e n.

Det som mangler i denne undersøkelsen er selvsagt de andre aktørenes opplevelse av det å bruke av tolk i rettssalen, ettersom denne undersøkelsen kun innhenter svar fra tolkene selv.

19 Den samme formuleringen ble brukt i fire spørsmål hvor 'dommeren' ble byttet ut med 'aktor', 'forsvarer' og 'tiltalte/siktede/vitner'. 


\section{Konklusjon}

Som vi ser har det vært gjort mye for å løfte tolkeyrket i Norge i de senere årene, og når vi i spørreundersøkelsen finner at 71 prosent av rettstolkene betrakter seg selv som likeverdige de andre aktørene i en rettssak, kan dette bety at økt utdanning og kursing har gitt tolkene en positiv yrkesidentitet. På den annen side er det fremdeles mye å gjøre med hensyn til å fremme synet på tolkeyrkets profesjonalitet overfor de andre aktørene i retten. Når det er så stort sprik i kvaliteten på tolker som eksemplene i denne artikkelen viser, blir det vanskelig for tolkeyrket å få den anseelse av andre profesjonsutøvere som er nødvendig for at det skal bli betraktet som en synlig profesjon på lik linje med de andre aktørene. Tolken i eksempel 1, 2 og 3 oppfattes av de andre aktørene i retten som tolk, blir betalt som tolk og utfører en arbeidsoppgave som tolk (når man ser bort fra kvaliteten). Men er han/hun en tolk? Er en tolk bare en som oversetter muntlig? Er man lærer når man viser noen hvordan et regnestykke skal regnes ut? Og er man sykepleier om man legger bandasje på et sår? Er ikke et yrke - en profesjon - noe som er et resultat av en formalisert opplæring, det vil si en utdanning, og som i noen tilfeller skal kunne sertifiseres? Hvordan kan vi i Norge stole på at tolker uten utdanning, og derved profesjonalisering, ivaretar rettssikkerheten til de som forstår minst av det som foregår $i$ retten, nemlig de siktede/tiltalte som ikke bare møter et ukjent språk, men også et ukjent rettsvesen? En uprofesjonell tolk står videre i veien for at de andre aktørene i rettssalen kan utføre sitt yrke profesjonelt og være sikre på at det som blir oversatt i rettssalen er det som sies og høres på norsk. På denne måten er uprofesjonelle tolker med på å true rettssikkerheten. Selvsagt vil det også blant tolker finnes noen som er bedre eller dårligere i sin yrkesutførelse, slik man har i alle yrker, men grunnlaget må være til stede: Tolken må være en synlig og likeverdig aktør i retten. Dette kan kun oppnås gjennom fokus på økt profesjonalisering og kvalitet, noe som igjen vil føre til bedre anseelse.

Når det gjelder Tolkeportalen, har denne en funksjon når det gjelder å kategorisere tolker i forskjellige nivåer, og vi så av figur 3 i spørreundersøkelsen at tolker på de øverste nivåene brukes mest. Det er imidlertid interessant at tolker på nivå 4, oversetterne, synes à være de som har minst profesjonsfølelse, både fordi de ikke anser seg selv som likeverdige yrkesutøvere og fordi det er de som føler seg minst synlige i retten. Tolker på nivå 5 er de minst kvalifiserte, og det er et tankekors at 53 prosent av denne gruppen likevel tolker minst tre ganger i retten i året.

Konklusjonen på denne gjennomgangen, slik artikkelforfatteren ser det, er at tolkregisterets nivå 1-3 bør bestå, mens nivå 4, oversetterne, ikke bør være oppført i registeret før de har tatt tolkeutdanning, og at det på nivå 5 kun bør være oppført tolker i de språk det ikke ennå har vært gitt tolkeutdanning i. 


\section{Referanser:}

Angelleli, C. (2004). Revisiting the Interpreter's role. Amsterdam: John Benjamins. http://dx.doi.org/10.1075/btl.55

Brante, T. (2011). Professions as Science-Based Occupations. Professions and Professionalism, North America, 1, Nov. 2011. Hentet fra: https://journals.hioa.no/index.php/pp/article/view/147/143. [Lesedato 23.3.2013] http://dx.doi.org/10.7577/pp.v1i1.147

Evaluering av Nasjonalt tolkeregister (2011). Hentet fra: http://www.tolkeportalen.no/no/Nyheter/Evaluering-av-Nasjonalt-tolkeregister/ [Lesedato 23.3.2013]

Informasjon-om-utarbeidelse-av-tolkeutdanningen. (Udatert). Hentet fra http://www.hioa.no/Studier/LU/Soknad-og-opptak [Lesedato 28.8.2014]

Mikkelson, H. (2000). Introduction to Court Interpreting (Translation Practices Explained). Manchester: St. Jerome Publishing.

Nilsen, A. B. (2005). Flerspråklig kommunikasjon i rettssalen. En kasusstudie av en flerspraklig rettsforhandling. Oslo: Det humanistiske fakultet, Universitetet i Oslo.

Nilsen, A.B. (2011) Tolkens Makt. Dagbladet. Hentet fra: http://www.dagbladet.no/2011/10/28 [Lesedato 23.3.2013]

Nilsen, A.B. (2012). Tolking og rettssikkerhet. Powerpointpresentasjon. Hentet fra: https://docs.google.com/presentation/ [Lesedato 30.12.2013]

Pöchhacker, F. (2004). Introducing Interpreting Studies. London: Routledge.

Prinsipprogram for Norsk Tolkeforening (2007/2008): http://www.tolkeforeningen.no/om ntf.php [Lesedato 30.8.2014]

Rett til tolk.(2005). Tolking og oversettelse i norsk straffeprosess. Hentet fra: http://www.regjeringen.no/nb/dep/jd/dok/rapporter_planer/rapporter/ [Lesedato 23.6.2013]

Skjult Informasjon - apen kontroll. NOU, (2009): 15. Hentet fra http://www.regjeringen.no/nb/dep/jd/dok/nouer/2009/nou-2009 [Lesedato 23.6.2013]

Tolkeutdanning - historikk. (2009, 2011). Hentet fra: http://www.tolkeportalen.no/no/For-tolker/Utdanning/ [Lesedato 28.08.2014] 